\title{
Family Firms and Brand Products in Malaysia: Originality, Productivity and Sustainability
}

\author{
EDMUND TERENCE GOMEZ AND WONG YEE TUAN
}

\begin{abstract}
Two key questions in Malaysia's corporate history have not yet been answered. Why is it that only a small number of family firms produce brand products? Why has none emerged as a major publicly listed enterprise? This study employs concepts from family business literature as well as Alfred Chandler, Jr's business history approach to answer these questions. A blend of conceptual tools from these two bodies of literature offers insights into the evolution of these brand product family firms. By adopting this approach, this study reveals that the core issues requiring scrutiny are an enterprise's volume of investments in research and development, a skilled managerial team and an effective marketing technique. Other issues include the need for a sound succession plan and a focus on a horizontal form of enterprise development. This article also reviews the capacity of the state to enable as well as hamper the rise of domestic brand product firms.
\end{abstract}

Keywords: family firms, Chandler, brand products, Malaysia

\section{The Puzzle: Family Firms and Brand Products}

A major concern about family firms with a long and leading presence in the Malaysian economy is that they have no reputation for producing brand products, i.e., a consumer good or service embodied in a trademark, design or symbol that has emerged as a household name (Acker 2002; Anholt 2005). This is the case even though families control about 40 per cent of publicly listed companies, while the top ten families own a quarter of total market capitalization of the country's stock exchange, Bursa Malaysia. Three of the top ten quoted firms are family controlled.

Only a handful of small and medium-sized family firms have produced brand products of local and international repute. Four such brand products are Boh tea, Eu Yan Sang Chinese medicine, Yeo Hiap Seng bottled drinks and Royal Selangor handcrafted pewter ware. It is interesting as well, that not all these families have publicly listed their 
firms and none has emerged as a major corporate enterprise in Malaysia, in terms of market capitalization. Crucially, not all of these four brand products remain under the control of the founding family.

Given this situation, the study will deal with two key questions. First, what distinguishes this handful of family firms that have shown the capacity to produce brand products? Second, why is it that these family firms that produce brand products have not emerged as major publicly listed enterprises?

\section{Linking Family Enterprise and Business History}

Studies of family firms seldom if ever attempt to incorporate the tools of analysis provided by Alfred Chandler, Jr. (Chandler 1962, 1977, 1990; Chandler et al. 1997). ${ }^{1}$ This study will use conceptual tools provided by the bodies of literature that focus specifically on family firms and business history. These two bodies of literature have not been used together when analyzing the factors that aid the development of brand products within an economy.

In the literature on family firms, key topics of concern include succession planning, public listing, professionalization of management and research and development (R\&D). ${ }^{2}$ These core factors determine the sustainability or demise of family firms, as well as their capacity to produce brand products. Chandler's business history, on the other hand, entails an exhaustive assessment of the firm from within, in particular its organizational and managerial structure from the moment of its incorporation. His primary concerns are two-fold: when and how change occurred within a firm, and the 'organizational capabilities' of the enterprise, specifically its capacity for cumulative learning (Chandler 1990). The firm's ability to establish strong vertical roots in its production process was also of crucial concern to Chandler, though he concedes that there are periods when diversification might be necessary. Diversification can determine the progress or demise of a firm at important junctures in its history. The rise or fall of a firm depends primarily on whether it invests enough in three key areas: manufacturing, marketing and management (Chandler 1990).

Chandler employs the concept 'administrative coordination' to draw attention to the need for managerial hierarchies embedded in an enterprise with professional control structures separate from ownership. The growing professionalization of a company's management is important in the long run, to avoid institutional failure (Chandler 1977). 
Administrative coordination is inadequately emphasized in the family firm literature, even though the literature stresses the need for such companies to incorporate professional managers.

According to pioneering works in the literature on ownership and control, such as Berle and Means (1967) and Penrose (1959), transitions in a business from family ownership to managerial control can bear greatly on its development. In the family business literature, transitions in ownership and control are discussed in the context of 'generational change', brought about when a family firm is taken over by descendants (Gomez 2007; Wong 1985). Chandler and Penrose discuss the (three) stages of enterprise evolution: a business starts as a partnership before evolving into a sole proprietorship or a family firm. This is because partnerships are seldom sustainable in the long term. In the third or final stage, the firm will evolve in such a way that it can be described as an enterprise under managerial control (Chandler 1962, 1977; Penrose 1959). While the transition period from a partnership to single ownership or a family-owned enterprise can be quite rapid, the evolution to managerial control normally takes a generation or two (Chandler 1962, 1977; Penrose 1959).

Chandler argues that the growth of modern industry is primarily due to its capacity to upgrade its technology for mass production, referred to as R\&D. To upgrade technology and boost distribution, managers have to look internally, at the firm's organizational structure, to rectify or introduce new mechanisms to augment innovation and increase the market share of the firm's products (Chandler 1977).

However, Chandler underestimates the family's contribution to growth and efficiency. Dyer (1986, 2003), Jones and Rose (1993), Daily and Dollinger (1992) and Colli (2003) emphasize the intertwining relation between family and business in the development of family firms. Family knowledge and interests shape every dimension of the enterprise: strategy, governance, organizational structure and succession. Family control and ownership patterns determine whether the enterprise survives or fails. If the controlling shareholder(s) is prepared to adapt to management and technological change, the family factor need not hinder the growth of the business.

Chandler inadequately tackles other important factors common among family firms in Asia. The issue of networks is of core concern in the literature on corporate development in Asia, specifically in studies of Chinese enterprise (see, for example, Hamilton 1996; Wong 1985) and of the political economy of development involving the nexus between the 
state and capital (see, for example, Gomez 2009; Hewison, Robison and Rodan 1993; Wade 1990). The ostensible capacity of business networks to create tightly knit, interlocking ownership and directorship ties has been debunked (Gomez 1999; Gomez and Hsiao 2004). However, cooperative ties to coordinate production, distribution and consumption of products and services are well noted, creating what has been referred to as a form of 'network organization', apparently a unique institutional feature of Asian capitalism and a system that is distinctive from the Western notion of bureaucratization and efficiency (Whitley 1992). These production networks, however, do not form in a single dimension but primarily comprise chains of producers or sub-contractors that operate at multiple levels and whose membership changes over time. The research in this study further corroborates the point that production networks are not sustained over a protracted period, but are subject to change when new technologies are introduced to improve the quality of products produced.

The political economy literature, while providing an extensive appraisal of the role of the government in encouraging enterprise development, notes the rather diverse patterns of corporate growth adopted by firms selected for patronage. In Japan, the keiretsu system was instituted, while the emphasis of the Taiwanese state was on nurturing small and medium-scale enterprises (Wade 1990). In South Korea, Indonesia, Thailand and Malaysia, well-connected firms adopted a conglomerate pattern of growth (Amsden 1989; Gomez 2009; Rodan et al. 1997). In all these Asian countries, the companies privy to state patronage were primarily family owned (Gomez 1999; Jesudason 1989; Searle 1999).

It is also important that the historical relationship between the state and family firms in Asia has been fraught with friction because different groups hold political and economic power and decisions determining how state-generated resources are distributed are not always made with the aim of promoting an economic sector or developing domestic enterprise. The pattern of power distribution and the consequence of power shifts due to political struggles have had serious repercussions on the ownership and control of family firms (Rodan et al. 1997). What is also needed is an analysis of the political and economic context in which the firm exists, to assess the conditions within which it has to operate and adapt in order to rise within the corporate sector. 


\section{Methodology: Case Studies}

In this article, four family enterprises are examined in historical and comparative perspective: Eu Yan Sang International, Royal Selangor International, Boh Plantations and Yeo Hiap Seng. These family firms share common features that facilitate comparison, not just with each other, but also with other major enterprises in Malaysia not associated with a particular brand product or service. All four are in manufacturing, producing goods that have achieved national or international acclaim. All have a long history, having started up in the colonial period and come under the control of a second or third generation, although in one case the founding family has lost control. All have experienced a number of crises, leading in some cases to near collapse.

\section{Eu Yan Sang International - Traditional Chinese Medicine}

In 1879, a general provisions shop, Yan Sang, opened in Gopeng, in the state of Perak. Eu Kong, the founder, sold Chinese goods, including medicinal products, and remitted money to families of migrants from rural China. He subsequently diversified into tin mining and revenue farming (taxes on opium, alcohol, gambling and pawnbroking) (Chung 2002: 588-593; Sharp 2009: 14; Yeung 2006: 13). His key concern was to accumulate capital, not to gain a reputation in a particular industry.

The founder's only son, Eu Tong Sen, recognized Chinese medicine had become a popular product. Around 1910, he attached the family name to his company's medicinal products (Chung 2002: 582; Sharp 2009: 52). The name Eu Yan Sang (EYS) reflected the bond between the Eu family and the enterprise Yan Sang. 'Yan Sang' in Cantonese means caring for mankind. The company established branches in towns around the Malay Peninsula and two branches in Hong Kong and Canton. A team of managers comprising family and non-family was recruited to monitor and coordinate administration. Strict production measures were introduced to ensure high-quality herbal medicine, a clear investment by Tong Sen in management and R\&D. EYS branches functioned not merely as distribution outlets but also as procurement centres and processing factories. Raw herbs were selected in Hong Kong and shipped and distributed to the branches in Singapore and Malaya, where they were processed, categorized and sold. EYS' marketing entailed the processing and sale of herbs by hand, a personalized service that helped increase its clientele. 
By the time the third generation took over the enterprise in the 1940s, in keeping with theorization by Penrose (1959) and Berle and Means (1967), professional managers had been entrusted with running the business, which further contributed to its development. Lo Kwee Seong, a Hong Kong-based manager with a university degree in economics, invented new packaging for EYS, so the firm became the first to sell Chinese medicine in pill and capsule form (Sharp 2009: 101). Yeung Chi Poh, a general manager, established the Weng Li Company to centralize purchasing Chinese herbs and traditional medicines from China and Hong Kong, which greatly improved quality control (Yeung 2006: 145-146). Production was centralized in Hong Kong and Malaysia. By centralizing purchasing and manufacturing, EYS achieved greater profitability. An aggressive series of creative marketing and brand-building campaigns through the media, especially television, was used to promote EYS as a major manufacturer of Chinese traditional medicine. In 1973, EYS was publicly listed in Singapore, but ownership was reduced by a mere 25 per cent. Four outsiders were appointed to the board of directors, while only three Eu brothers remained as directors (Sharp 2009: 130; Yeung 2006: 142).

Family solidarity began to break down when the fourth generation took charge in 1989. Richard Eu Yee Ming, son of Eu Keng Mun and grandson of Tong Sen, was appointed general manager at EYS Holdings (Sharp 2009: 131; Yeung 2006: 148). Yee Ming formulated an ambitious five-year expansion plan. However, not all the third-generation seniors agreed, and some began selling their shares to Lum Chang Holdings, the largest construction firm in Singapore. Tong Sen's other sons living abroad divested their equity, as they felt geographically and psychologically distanced from Eu family affairs. They saw little need to retain an interest in the firm, which had paid relatively poor dividends (Sharp 2009: 132). In 1990, Lum Chang took over EYS Holdings. This takeover almost led to its demise, for Lum Chang's primary aim was to develop its property business through a listed vehicle, as well as to capitalize on its properties.

In 1993, Yee Ming and three cousins spearheaded a successful buyout of EYS from Lum Chang. Family strife again erupted in 1996, when Charles Eu, a member of the third generation in charge of the Hong Kong operation, demanded the right to use the EYS international trademark and filed a lawsuit against EYS International in Singapore. He also wanted to install two associates, members of China's People's Liberation Army (PLA), on the board of directors (Sharp 2009: 135-136). 
Shareholders met to sack him, and EYS Hong Kong was taken over by EYS International of Singapore and delisted from the Hong Kong Stock Exchange. It was consolidated as a single company and Yee Ming and his cousins became the major shareholders.

Under their leadership, more non-family members were appointed to the board of directors, an executive management team was introduced to oversee the group's operations, and big investments were made to enhance product development and marketing. By 2010, the board of directors had an equal number of family and non-family members. In 2000, EYS invested HK\$24.5 million in R\&D, chiefly by linking up with universities. The company worked with the Chinese University of Hong Kong to produce the Bang Fong Pill, a traditional medicine to enhance women's health. In 2001, a joint venture with West China (Huaxi) University of Medical Sciences developed herbal medicines to treat lifestyle diseases. ${ }^{3}$ Through such R\&D-based joint ventures, the firm introduced more than 300 products under the EYS brand and more than 1,000 Chinese herbs and medicinal products. To market this huge range, around 150 additional retail outlets were established in China, Hong Kong, Macau, Taiwan, Malaysia and Singapore. EYS also retails its products through wholesale chains such as Watson's, Wellcome and PARKnSHOP in Hong Kong; Jaya Jusco, Wellsave, Makro and Parkson's in Malaysia; and Guardian and Cold Storage in Singapore. ${ }^{4}$ EYS has emerged as the largest Chinese medicine retail chain in Hong Kong and Southeast Asia.

\section{Royal Selangor - Pewter Products}

In 1885, Yong Koon arrived in Kuala Lumpur from China to join his two brothers, working as tinsmiths. They established an enterprise that produced simple household and ceremonial items such as pewter incense burners, joss-stick holders and candle stands for Chinese altars. Yong Koon acquired a shop-house and incorporated Malayan Pewter Works, but the Great Depression hit the firm. The recession contributed to a major change in product output. G.H. Hutton, an English engineer, advised Yong to take advantage of the low price of tin to produce European-style products such as cigarette boxes, ashtrays, vases and teapots (Chen 2003: 22-27). This horizontal diversification allowed Yong to capture a new market.

As the patriarch of the family aged, the four sons took charge of the enterprise in the mid-1930s, but were soon at loggerheads. This led to a split, with each brother incorporating a pewter company: Tiger Pewter, Selangor Pewter and Lion Pewter (Chen 2003: 33; Toyad and Gopinath 
2010: 10). Only Selangor Pewter, run by the third brother, Yong Peng Kai, survived.

Selangor Pewter thrived when Peng Kai improved manufacturing by introducing machinery and hired workers to create a production line. In 1962, the company changed from home-based production to a factory-based enterprise. This transition was in response to a government policy to support local industry. The government provided the firm with a loan of 150,000 Malaysian ringgit, as well as three consultants from the International Labour Organization, to enable the factory to function efficiently (Chen 2003: 63). The enterprise created a work plan and enhanced its mechanization.

Peng Kai invested in tertiary education for his children and relatives, so they would have professional expertise to benefit the business. Yong Poh Kon, his youngest son, who studied mechanical engineering at the University of Adelaide in the 1960s, introduced new production processes, including hydraulic presses and alloying metals. A joint venture with Soltauer Zinngiesserei allowed the firm access to German technology for casting pewter using steel moulds (Chen 2003: 75). Guay Boon Lay, Peng Kai's niece, who had a talent for art, was sent to Bristol Art College in the UK in 1970; she returned to head the company's design department (Chen 2003: 70). Peng Kai hired a professional designer, Anders Quistgaard, from Denmark, who established a House Design Committee to evaluate new designs. The contribution made by Poh Kon and Boon Lay to new production techniques and skill formation on the shop floor greatly increased the quality and range of products.

Aggressive marketing was also used. Brochures and catalogues were sent to agents throughout the country as well as to Europe and North America. Media outlets, especially local and overseas newspapers, were used to advertise products. Pewter showrooms were launched in Malaysia's major towns (Beamish 2000: 232). The firm established offices in foreign markets and promotional teams demonstrated how the products were made. An extensive network of 70 shops and hundreds of in-store counters worldwide displayed and marketed the products. As its international prestige grew, the government in 1979 bestowed the name 'Royal Selangor'.

When the third generation took the helm in 1980, the firm's management was further professionalized. The board of directors, once exclusively the domain of the Yongs, now includes outsiders: Tham Tuck Yong, a British-trained engineer, is the executive director in charge of 
day-to-day operations; C.Y. Wong, who joined the firm in 1984, is the president of Royal Selangor USA and oversees the North American market; and Peter Coleman is the managing director of Royal Selangor UK (Chen 2003: 112). They were appointed as company directors in 2002. Fourth-generation family were appointed to management, including Yong Yoon Hong, the corporate graphics manager who once worked for the UK design consultancy Addison Nelson, and Sun Chee Yan, the information-technology manager who once worked with DHL Worldwide Express and Hewlett-Packard (Chen 2003: 113).

By 2002, 55 per cent of Royal Selangor's turnover was from sales abroad, in 25 countries, compared with just 2 per cent in 1972 (Anholt 2005: 67). The firm has emerged as the largest global producer and distributor of pewter ware gifts.

\section{Boh Plantations - Tea}

The founder of this enterprise, John Archibald Russell, was first employed by the Straits Trading Company in Malaya in the early 1900s. In 1904, he established J.A. Russell \& Company, initially in tin mining, though he diversified into coal mining, rubber planting, manufacturing and property development (Wong 2010: 29-30). After the crash of commodity prices in 1927, Russell decided to plant tea, whose price had remained stable. In 1929, the well-connected Russell, together with A.B. Milne, a veteran tea planter from Sri Lanka, obtained a grant of 4,000 acres of land in Cameron Highlands from the federal government. Boh Plantations was incorporated to cultivate tea on this land.

The first harvest was sold to a Chinese contractor, who converted it into a semi-fermented tea that found a ready market among the Chinese on the Malayan plains. When a factory was built in 1934, tea was prepared for export; the first consignment was sold in London. Russell did not survive to see this: he died suddenly in 1933. His untimely death, coupled with the Great Depression, seriously affected his business empire. Kathleen, his wife, sold all his ventures, keeping only the plantations. The funds from the sale were used to continue financing the plantations, which came under the management of professionals. ${ }^{5}$ In 1949, Russell's only son, Tristan, who had completed undergraduate studies in agriculture in England, took charge.

Before World War II, Boh Plantations had exported mainly to the UK, then the world's chief consumer of tea. When the UK imposed restrictions on tea imports, Boh Plantations' profits fell. In the post-war period, the company focused on creating a domestic market in response to growing 
demand. Tea imports from Sri Lanka, India and China had been increasing in the post-war period. In 1947, 5 million pounds were imported, compared with 3.75 million pounds in $1931 .{ }^{6}$ Later, Boh Plantations faced less competition locally because import duties were levied. Price and quality were both key factors; Boh tea was graded as equal to highquality Sri Lankan tea. By 1947, about 50 per cent was sold locally.

To expand Boh Plantations' domestic market share, Tristan increased production and marketed aggressively. Professionals were employed to organize and oversee operations. The factory was modernized and a larger labour force was employed to work on the plantations, while newspapers and television were used to publicize the product. In the mid-1950s, a cartoon character, 'Mr. Boh', was created for use on Malaysian television, one of Asia's first televised company mascots ${ }^{7}$ (Street 2005: 33). An extensive distribution network was created, through agents and retailers employed throughout the peninsula.

As a foreign-owned enterprise, the company's most serious concern was the government's affirmative action-based New Economic Policy (NEP), which was introduced in 1970. The NEP legislated extensive state intervention in the economy and the transfer of at least 30 per cent of Malaysia's corporate equity to Bumiputera ${ }^{8}$ by 1990 . This policy unnerved the Russells, who were confronted with the possibility of relinquishing a major interest in their company to an outsider chosen by the government. The family diverted investments abroad, to Australia, Britain and the United States, a move that undermined the development of Boh Plantations. However, the family succeeded in retaining managerial control by allowing Permodalan Nasional Bhd (PNB), a government investment agency, rather than an individual to own 27 per cent of its equity.

With the issue of managerial control resolved, growing and manufacturing continued to be modernized and mechanized, particularly in harvesting, fertilizing and packing. When labour costs rose, the company introduced harvesting machines. Mechanical tea harvesters were used on the lowland gardens and portable hand-operated machines on the highland estates. Air tractors were used to fertilize the plantation. The packing factory was upgraded with the installation of high-speed Perfecta teabag packaging machines. This German technology could turn out 350 string and tag bags a minute.

Caroline Russell, Tristan's daughter, who joined the family business in 1988 after graduating with a degree in commerce from the University of Edinburgh, introduced and spearheaded innovative marketing 
strategies. John Russell, the younger son and a software designer who runs a software firm in the US, designed and implemented computer programmes to make the company's administration and management more efficient. Caroline rejuvenated the Boh brand by changing the packaging while introducing new products. With its striking graphic designs and colours, the new packaging reflected a bolder and brighter corporate image. ${ }^{9}$ The company introduced a variety of new products, ranging from the Seri Songket-flavoured tea to fruit and herbal infusions, ice tea and a three-in-one instant tea mix. Each product was designed to cater to the needs of a specific consumer group: tea connoisseurs, health enthusiasts, stressed office workers and tourists. ${ }^{10}$

Astute management by the third generation has kept the brand relevant, changing with the times to allow Boh Plantations to retain its position as Malaysia's leading tea enterprise. The company controls 60 per cent of the domestic market and about 5 per cent of production is exported to Singapore, Brunei, Japan, the US and Denmark.

\section{Yeo Hiap Seng - Soft Drinks}

In 1900, Yeo Kheng Lian established Yeo Hiap Seng (YHS), a soy-sauce factory, in Fujian province in China. In Chinese, 'Hiap Seng' means unity or unite to succeed. Due to political turmoil, the Yeo family moved the business to Singapore in 1935. Later, the factory was expanded to increase production, while a manufacturing plant was established in Malaya (Lee and Li 2009: 3). YHS grew rapidly by diversifying into canned food and bottled drinks. It went on to capture a large section of the soft drink market by catering to Chinese tastes that the British-based Fraser \& Neave Ltd (F\&N) had ignored (Gomez and Hsiao 2004: 22). In 1955, YHS became the first company in the world to introduce soybean milk. ${ }^{11}$

One of the Yeo sisters reputedly invented the soybean milk recipe, and the technology to bottle the product was jointly developed by Tan Chee Teck, son of the eldest Yeo sister, and his cousin Yeo Chee Kiat. Bottled soymilk became YHS' best-known product. In 1967, YHS scored another world first by packing herbal tea and bottling sugarcane juice. In 1984, YHS made a breakthrough by developing and packing carbonated tropical fruit drinks such as pomelo and sour sop, unique to Southeast Asia. ${ }^{12}$

To boost production to cope with growing demand, the Yeo brothers automated their factory. A bottling line was introduced with a capacity of 1,000 bottles per minute, at the time, the fastest in Southeast Asia (Lee and Li 2009: 28). They also created an extensive marketing network 
comprising a chain of sales offices, warehouses and depots to distribute the company's products in Malaysia and Singapore and abroad. Area sales managers and teams of salespeople were recruited to provide customers with direct personal services. These strategies helped YHS win a lion's share of the soft drink industry in Singapore as well as the reputation of a pioneer in this sector in Southeast Asia.

As more family members came to Singapore and joined the enterprise in the 1950s, a management team began to take shape. Three pioneers managed the main operations: Yeo Thian In took charge of factory production; Yeo Thian Kiew handled sales; and Yeo Chee Kiat was responsible for plant equipment, machinery and product development. Top management was dominated by the founding family members of the second generation. Thian In became the permanent chairperson and general manager; Thian Soo served as the vice chairperson; and Chee Kiat assumed the position of finance director (Lee and Li 2009: 25). Other family members took posts in middle and lower management.

To raise capital for further expansion, Yeo Hiap Seng Holdings, a family firm, was formed to control the public company, Yeo Hiap Seng Ltd, which was listed on the Singapore stock exchange in 1969. In 1975, YHS (Malaysia) Ltd was quoted on the Malaysian stock exchange (Brown 2000: 77).

When the third generation of the family took control in 1985, problems emerged in YHS Holdings, now jointly owned by six families (Lee and Li 2009:5). Family members were divided on matters of investment and management. Family feuds became more intense when Alan Yeo Chee Yeow, third son of Thian In, became chairperson and president. Under Alan's leadership, in 1989 YHS Ltd teamed up with Temasek Holdings, the Singapore government's investment arm, to buy the troubled USbased Asian food company, Chun King Corp (Brown 2000: 83; Friedland 1989: 108). This US\$52-million investment, which absorbed much of YHS Ltd's cash reserve, turned out to be a disaster. This failure showed that YHS lacked the organizational and managerial competence to penetrate markets in North America.

In 1992, Alan made another controversial decision, asking four relatives to relinquish their senior managerial appointments so he could incorporate non-family members into executive positions. Intra-family hostilities increased when he tried to acquire 140,000 shares in his son's name to obtain more than 50 per cent ownership of the firm, and thus control over decision making (Lee and Li 2009: 6). When he unilaterally supported Wing Tai Holdings' bid to acquire between 25.5 and 40 per 
cent of YHS' equity, family members compelled him to resign (Brown, 2000: 85; Lee and Li 2009: 6-7). This confrontation led to the liquidation of YHS Holdings when family members sold off their shares.

Robert $\mathrm{Ng}$ Chee Siong and $\mathrm{Ng}$ Teng Fong of the Sino Land Group won control of the company in 1995. The $\mathrm{Ng}$ family now controls a majority of shares, leaving the Yeo family with almost no equity in the company it had founded nearly a century before. Since the $\mathrm{Ng}$ family's primary interest is property development, they have invested insufficiently in YHS' drinks business. As a subsidiary business of a property-based conglomerate, YHS' reputation as a powerful brand name in the soft drinks industry has declined.

\section{Brand Products, Family Firms and Sustainability}

\section{Product Development and R\&D}

Each of these four family firms created a brand product by cultivating expertise in a specific industry. All four firms pursued a three-pronged strategy of investing in manufacturing, management and distribution to acquire competitive advantages, or in some cases, such as YHS and Royal Selangor, 'first-mover' advantage. In all cases, these families managed to create a 'brand identity' that remains instantly recognizable, a factor that aids consumers' purchasing decisions. Investments in R\&D proved imperative in all cases to create a unique product, but a key factor that differentiated their products from others in the market was effective design, packaging and advertising techniques, all central to creating a brand identity.

EYS, YHS and Royal Selangor developed products unique to Malaysia, but realizing how increasingly competitive the market was becoming, they also invested substantially in R\&D to improve or diversify their product base. R\&D to enhance skill formation led to new or improved products and innovative production techniques that allowed them to stay ahead of the competition, particularly in the case of Royal Selangor and YHS (Penrose 1959: 134).

All four firms invested in technology to increase production capacity. Joint ventures, particularly with foreign firms, allowed EYS and Royal Selangor to learn new technology crucial for product innovation. Product innovation diversified their range of products to keep buyers interested and increased their customer base and sales volume (Beamish 2000: 227). 
By linking with tertiary institutions in Hong Kong, China and Singapore, EYS was able to carry out research to diversify into the manufacturing of traditional pills, capsules and powders, thus opening yet more new markets. This horizontal diversification enabled EYS to revitalize its brand once the Eu family had regained control of the enterprise, suggesting the importance of family legacy for sustaining a product.

\section{Enterprise Development, Public Listing and Feuding}

Founding members had an acute sense of stakeholder loyalty that contributed to aggressive reinvestment, and groomed their children from an early age to take over the enterprise. However, all these evidently entrepreneurial family firms remain medium scale in terms of market capitalization, though their relatively small size is not necessarily by choice, and is due primarily to family feuds, which occurred in all cases except Boh Plantations. Family feuds of this sort are a core reason why some firms have not been able to maintain control over their brandproduct business.

The main reasons family firms go public are the desire to increase personal wealth, diversify operations and obtain equity capital for expansion (Dyer 1986: 96-98; Ravasi and Marchisio 2001: 2-3). This is why EYS and YHS went public. However, public listing appears to have contributed to the loss of family control of both firms. The sale of equity by family members, following feuds, made it easier for outsiders to take control at a time when they were emerging as major publicly listed enterprises.

The reluctance of family firms to pursue public listing is cited in much of the literature as a fundamental weakness among such enterprises, caused by the family's desire to retain strong - and unaccountable - control. By remaining private, they need not divulge information that would make them susceptible to a takeover, either by other businesspeople or by the state. However, the lack of enthusiasm of firms such as Boh Plantations and Royal Selangor for public listing has not held them back from marketing their products, domestically and abroad. They have attracted professional managerial staff. This suggests that public listing is not crucial to create brand products.

Issuing stock to the public means expanding ownership of a business, but a family can retain control if they maintain a majority stake. However, with the appointment of non-family members to the board of directors, and the family's growth in size and emergence of a new generation, management can become increasingly fractious. The interests 
of public owners and the family can diverge. Public owners, including institutional investors and non-family investors, are generally more interested in short-term financial returns, while families typically pursue longer-term goals and emphasize issues such as status in the community (Davis 2008: 140). If a publicly listed firm encounters a problem of succession, family feuds can intensify and eventually put ownership and control at risk. The cases of EYS and YHS show how intergenerational succession can lead to family feuds that contribute to takeovers.

The case studies show that family firms listed on the stock exchange are particularly prone to takeovers in succession crises. Companies that remain privately owned are also susceptible to feuds, but as the case of Royal Selangor indicates, family members of a private enterprise need not in such cases lose ownership of the product they have created. This is because only family members have the commitment, skills and knowledge to continue to develop the product. The families of publicly listed enterprises like YHS that fall to outsiders are likely to lose ownership of the product, whose market share may decline.

\section{Generational Change and Succession Planning}

While founders of family firms attempt to perpetuate their legacy and ensure family control when generational change occurs, ensuring a smooth succession has proved difficult. Succession, as the case studies indicate, was an epochal moment in their corporate history. Improper handling led to their division, dismantling or takeover. Such problems arose when those taking the helm failed to establish authority or gain the support of other family members (Dyer 1986; Rose 1993).

The case studies show that the principal reason for family feuds when generational change transpires lies in problems with the enterprise's leadership. Family feuds occurred in all cases except Boh Plantations, where the Russell family experienced little problem with the succession. Three factors - succession planning, the strongly paternalistic role of predecessors and a small number of siblings in the family business - contributed to the smooth succession in Boh Plantations. These factors were absent from the other firms.

For the Eu family, the third generation, which was not involved in managing the family business, played no strong paternalistic role in preparing the fourth generation to take charge. In the Yong family, Yong Koon, the patriarch, did not designate a successor from among his four sons or design any governance structure to manage the family business. Although there was succession planning in the Yeo family, the 
number of siblings and cousins given control of the family enterprise was far too large. The plethora of Yeo family members in management contributed to major disagreements over investment and shareholding, which harmed the business. The decline of YHS and EYS was mainly due to feuds among the second and third generations. It seems to be harder to sustain a relationship among cousins than among siblings, at least to judge from the case of YHS and EYS. However, in Royal Selangor, a dispute among the brothers led to the incorporation of new enterprises by each. The case studies indicate that building a unified shareholder vision after a generational transition is extremely difficult.

Whether or not a unified vision is created depends on who controls decision making following generational change. It is especially difficult when the chief executive from among the new generation lacks the support of his siblings and other family members who are shareholders. In such cases, each equity holder is likely to have his or her own vision of how the company should go forward, and stock holders seldom share a common vision. This issue was most evident in the case of Royal Selangor, EYS and YHS.

While family disputes can lead to the demise of firms, Royal Selangor suggests that siblings with expertise going it alone can foster competition that helps improve quality. This appears to be one reason why Royal Selangor thrived. Malaysian corporate history has cases of partnership feuds leading to new ventures in the same sector that contributed to more competition and improved efficiency and productivity, to the benefit of the domestic economy. ${ }^{13}$

\section{Horizontal Development and Organizational Capacity}

A core issue in the literature on family business and those adopting a Chandlerian perspective is whether they can diversify. This study of Boh Plantations, Royal Selangor, YHS and EYS suggests that a focused approach to enterprise development is imperative. The Eu and the Russell families gradually abandoned their diversified business interests and concentrated on one sector. The Yong and Yeo families, who engaged in product innovation by fine-tuning their organization, focused on only one business. A horizontal form of enterprise development rather than a diversified pattern of growth enabled these founding families to build a brand product and, in the case of Boh Plantations, EYS and Royal Selangor, to sustain it.

In all cases, a decision-making structure centred on the founder evolved into a more formal hierarchy with differentiated functions, 
through the recruitment of professionals to fill key managerial and specialist roles. This professionalization involved institutionalization of decision making and strategic planning; appointment of non-family professionals to managing positions; and the training of the younger generation as professional managers before entrusting them with important management tasks. EYS, Royal Selangor and Boh Plantations underwent this process of professionalization. The Eu family created administrative structures that coordinated the flow of materials to improve product quality. The devolution of authority to professional managers was necessary to accumulate shareable knowledge that in turn enhanced organizational capabilities. Royal Selangor's employment of a Dane in the design department increased its range of products, while EYS' managers in product development and distribution enhanced efficiency and improved profitability.

For the board of directors, the appointment of outsiders with different sorts of professional training helped with decision making and with the formulation and implementation of long-term strategic plans. EYS's six-member board of directors had three non-family members; Royal Selangor also had three, while Boh Plantations had two. In middle management, family professionals with tertiary education have been recruited to take charge of finance, marketing, purchasing, information technology and production. On the other hand, a similar level of professionalization of management did not happen in YHS, although this lack does not seem to have hindered the company's international competitiveness in the early stages of its growth. Even though there was an outsider on YHS's board of directors, family members dominated the management and the chairperson exercised a lot of authority.

\section{Role of the State}

The cases indicate that the state can play an important role in numerous ways to help nurture domestic enterprise. In the colonial period, J.A. Russell's associates in government granted him plantation land to produce tea, a viable industry that helped reduce imports. Royal Selangor's venture into large-scale manufacturing in the 1960s was due to the Malaysian government's policies to promote lucrative entrepreneurial enterprises in niche industries. Recognizing Royal Selangor's capacity to develop a unique pewter ware sector, the government provided aid and foreign consultancy services that helped this small, home-based operation evolve into a large manufacturing enterprise with work processes that improved quality and enhanced productivity. As the com- 
pany's reputation grew internationally, the title 'Royal' was bestowed, an endorsement that garnered it even greater respect domestically and abroad (Chen 2003: 61-62).

Other forms of state support to aid enterprise development have been attempted. The collaboration by the Singapore government's investment arm, Temasek Holdings, with YHS in the ill-fated acquisition of US-based Chun King Corporation was aimed at cultivating local industries by helping them expand their markets abroad. The government thought YHS had the expertise to use Chun King Corporation to nurture a market for its unique products in North America. The failure of this venture did not damage the relationship between the government and YHS, although it precipitated a family feud that eventually led to the firm's takeover.

The creation of close ties with the state, however, can have serious repercussions. While EYS' attempt to appoint politicians to the board of directors to secure access to government concessions often happens in large enterprises, in this case it contributed to a serious family feud. Charles Eu's proposed appointment of PLA members to the EYS board before the return of Hong Kong to China by the British drew the ire of family members, convinced this would lead to the takeover of the firm by politicians (Sharp 2009: 135-136). The close ties that J.A. Russell had established with prominent members of the British colonial government aided the early development of Boh Plantations. When affirmative action was introduced in Malaysia in 1970, partly to redistribute corporate equity more equitably between ethnic communities, influential politicians won access to a large stake in publicly listed and foreign firms, including board appointments, a factor that first led to transfer of assets abroad by the Russell family. The Russell family, however, managed to maintain ownership and control of the company by incorporating a government-owned institutional investor as a major shareholder, one that did not interfere with the management of the firm yet allowed Boh Plantations to maintain cordial though arms-length relations with the state. Since targeting under affirmative action has significantly re-shaped corporate ownership and control patterns, non-Bumiputeras have been reluctant to invest in $R \& D$ for fear that their firms may be appropriated by the state during redistribution endeavours to alleviate inter-ethnic wealth inequities (Gomez 1999, 2009; Jesudason 1989; Searle 1999). While Boh Plantations and Royal Selangor have invested in R\&D, they have bypassed active state intrusion in the ownership of their equity by not publicly listing their firms. 


\section{Conclusion}

This study set out to discover what features of family firms can produce brand products and to understand why such firms have not emerged as leading publicly listed firms in Malaysia. By employing concepts from the family business literature, in conjunction with a Chandlerian perspective that assesses the historical evolution of four family firms, insights have been obtained into these questions.

In all four firms, a common feature was that the families had invested heavily in product-specific modes of production, innovative distribution techniques and a professional managerial force. These features were particularly evident in firms that survived over three generations. The issue of strategic agility was equally crucial in dealing with economic or business crises. During a serious recession in the 1930s, Boh Plantations demonstrated an ability to focus on a core business and Royal Selangor to diversify its product range. This reflects another important feature of these four firms: in the early stages of development, sustaining growth required innovation through $\mathrm{R} \& \mathrm{D}$. In all cases, product-specific production and effective marketing were crucial in helping them create brand products. This emphasis on an organic mode of growth, to create competitive advantage through differentiation, meant that their products had a dominant presence in the market.

Other important factors, such as a succession plan and public listing, had a bearing on sustainability. The presence of a potentially predatory state was also a factor. For Royal Selangor and Boh Plantations, these two factors were crucial in allowing the Russell and Yong families to retain ownership and control. In both cases, the growing professionalization of management was vital to sustain organizational capacity.

Promoting organizational capacity is essential, given that business growth invariably slows (most graphically in the case of YHS), so that outsiders must be brought in to expand the firm's market share. In the case of YHS, family shareholders were reluctant to reduce their shareholding, even if this led to an expansion of the firm's market share. This suggests that, following generational change, retaining managerial control is difficult in family firms.

The core factor in all four firms was their ability to develop a brand identity, as well as to diversify the range of products produced under their brand name. Family members, who had the knowledge to develop and sustain this product, nurtured these brand identities. This was most obvious in the case of YHS and Royal Selangor. 
Loss of ownership and control to non-family members led to the decline of the product in the case of EYS and YHS. The case studies confirm why, following a takeover, these firms with brand products did not emerge as major publicly listed firms. In family businesses, the focus is on perpetuating ownership within the family to build an enterprise for future generations. This desire is greater than that of making more money, which suggests that to sustain the enterprise in the long run, families need to distinguish between ownership and control. Recognizing this distinction would mean moving to a managerial form of control, with families holding equity ownership. This may help families retain equity ownership in the long run while allowing them to increase shareholder value and augment their brand identity, primarily through R\&D.

Edmund Terence Gomez is Professor of Political Economy in the Faculty of Economics and Administration, University of Malaya. Email: etgomez@um. edu.my

Wong Yee Tuan is a Post-doctoral Research Fellow at the University of Malaya.Email: yeetuanwong@yahoo.com.au

\section{NOTES}

1 For an overview of the literature on family firms, see Aronoff (1998); Colli (2003); Daily and Dollinger (1991, 1992, 1993); Dyer (1986); Jones and Rose (1993); Sharma (2004); Sharma, Chrisman and Chua (1997); and Tàpies and Ward (2008).

2 Lambrecht and Lievens (2008) note, after reviewing articles published by the journal Family Business Review during its first ten years, that a majority of the studies focus on the issue of succession. This topic continues to feature as a key concern in the literature on family firms, with numerous debates of the factors that contribute to the sustainability of such enterprises over two or more generations.

3 Jacqueline Ann Surin, 'Eu Yan Sang big on R\&D'. The Star 12 March 2001, p. 22.

4 Ibid.

5 B.K. Sidhu, 'Wall Street crashes, Archie strikes Boh', The Star 7 May 2001, pp. 14-15.

6 One pound is equal to about 0.45 kilograms.

7 Mike Street, 'A Walk Down Memory Lane with Tristan Russell'. Malaysia History, September 2005. Available at: http://www.expatkl.com/magazinearticles/ sept0905_4.pdf (accessed 25 June 2010).

8 This term means 'sons of the soil' and is used with particular reference to one ethnic group, the Malays, though it also includes indigenous communities in the peninsula and in the Borneo states of Sabah and Sarawak.

9 Hanim Melan, 'Boh on the go'. Malaysian Business 16 May 1998, p. 33.

10 Hanim Melan, 'Boh on the go'. Malaysian Business 16 May 1998, p. 33.

11 Jacqueline Ann Surin, 'Yeo Hiap Seng went like a bomb during WWII'. The Star 19 March 2001, pp. 22-23.

12 Jacqueline Ann Surin, 'How the Yeo family lost their control'. The Star 19 March 2001, 
p. 23.

13 See Gomez (1999) for a study of the Oversea-Chinese Banking Corporation (OCBC), where a feud among the shareholders led to the incorporation of a number of banks that emerged as key players in the Malaysian economy.

\section{REFERENCES}

Acker, David 2002. Building Strong Brands. London: Simon \& Schuster.

Amsden, Alice 1989. Asia's Next Giant: South Korea and Late Industrialisation. New York: Oxford University Press.

Anholt, Simon 2005. Brand New Justice: How Branding Places and Products Can Help the Developed World. Oxford: Elsevier Butterworth-Heinemann.

Aronoff, Craig E. 1998. 'Megatrends in Family Business'. Family Business Review 11: 181- 185.

Beamish, Paul W. 2000. Asia Pacific Cases in Strategic Management. Boston: Irwin McGraw-Hill.

Berle, Adolf A., and Gardiner C. Means 1967. The Modern Corporation and Private Property. New York: Harcourt, Brace \& World, Inc.

Brown, Rajeswary Ampalavanar 2000. Chinese Big Business and the Wealth of Asian Nations. Basingstoke: Palgrave.

Chandler, Alfred D., Jr. 1962. Strategy and Structure: Chapters in the History of the American Industrial Enterprise. Cambridge: MIT Press.

Chandler, Alfred D., Jr. 1977. The Visible Hand: The Managerial Revolution in American Business. Cambridge: Harvard University Press.

Chandler, Alfred D., Jr. 1990. Scale and Scope: The Dynamics of Industrial Capitalism. Cambridge: Harvard University Press.

Chandler, Alfred D., Jr., Franco Amatori and Takashi Hikino (eds.) 1997. Big Business and the Wealth of Nations. Cambridge: Cambridge University Press.

Chen May Yee 2003. The Royal Selangor Story: Born and Bred in Pewter Dust. Kuala Lumpur: Archipelago Press.

Chung, Stephanie Po-Yin 2002. 'Surviving Economic Crises in Southeast Asia and Southern China: The History of Eu Yan Sang Business Conglomerates in Penang, Singapore and Hong Kong'. Modern Asian Studies 36 (3): 579-617.

Colli, Andrea 2003. The History of Family Business, 1850-2000. Cambridge: Cambridge University Press.

Daily, Catherine M., and Marc J. Dollinger 1991. 'Family Firms Are Different'. Review of Business 13 (1, 2): 3-5.

Daily, Catherine M., and Marc J. Dollinger 1992. 'An Empirical Examination of Ownership Structure in Family and Professionally Managed Firms'. Family Business Review 5: 117-136.

Daily, Catherine M., and Marc J. Dollinger 1993. 'Alternative Methodologies for Identifying Family vs. Non-family Managed Small Businesses'. Journal of Small Business Management 31 (2): 79-90.

Davis, John A. 2008. 'Toward a Typology of Family Business Systems'. In Family Values and Value Creation: The Fostering of Enduring Values within Family-owned Businesses, edited by Josep Tàpies and John L. Ward, pp. 127-154. Basingstoke: Palgrave Macmillan.

Dyer, W. Gibb 1986. Cultural Change in Family Firms: Anticipating and Managing Business and Family Transitions. San Francisco, CA, London: Jossey-Bass.

Dyer, W. Gibb 2003. 'The Family: The Missing Variable in Organizational Research'. 
Entrepreneurship Theory and Practice (Summer): 401-416.

Friedland, Jonathan 1989. 'Singapore's Yeo Hiap Seng buys into US food shelves: Taste for the West'. Far Eastern Economic Review 5 October: 108.

Gomez, Edmund Terence 1999. Chinese Business in Malaysia: Accumulation, Accommodation and Ascendance. Honolulu: University of Hawai'i Press.

Gomez, Edmund Terence 2007. 'Family Firms, Generational Change and Identity Formation: The Chinese in Britain and Malaysia'. East Asia: An International Quarterly 24 (2) Summer: 153-172.

Gomez, Edmund Terence 2009. 'The Rise and Fall of Capital: Corporate Malaysia in Historical Perspective'. Journal of Contemporary Asia 39 (3): 345-381.

Gomez, Edmund Terence, and Michael Hsiao Hsin-Huang (eds.) 2004. Chinese Business in Southeast Asia: Contesting Cultural Explanations, Researching Entrepreneurship. London: RoutledgeCurzon.

Hamilton, Gary G. 1996. Asian Business Networks. Berlin: W. de Gruyter.

Hewison, Kevin, Richard Robison and Gary Rodan (eds.) 1993. Southeast Asia in the 1990s: Authoritarianism, Democracy and Capitalism. Sydney: Allen \& Unwin.

Jesudason, James V. 1989. Ethnicity and the Economy: The State, Chinese Business, and Multi-nationals in Malaysia. Singapore: Oxford University Press.

Jones, Geoffrey, and Mary B. Rose (eds.) 1993. Family Capitalism. London: Frank Cass and Company.

Lambrecht, Johan, and Jozef Lievens 2008. 'Pruning the Family Tree: An Unexplored Path to Family Business Continuity and Family Harmony'. Family Business Review 21 (4) December: 295-313.

Lee, Jean, and Li Hong 2009. Wealth Doesn't Last 3 Generations: How Family Businesses Can Maintain Prosperity. Singapore: World Scientific.

Penrose, Edith T. 1959. The Theory of the Growth of the Firm. Oxford: Basil Blackwell.

Ravasi, Davide, and Gaia Marchisio 2001. 'Family Firms and the Decision to Go Public: A Study of Italian IPOs'. SDA Bocconi, Research Division Working Paper No. 0145. Milano: SDA Bocconi School of Management. Available at: http:/ / papers.ssrn. com/sol3/papers.cfm?abstract_id=278237 (accessed 12 May 2010).

Rodan, Garry, Kevin Hewison and Richard Robison (eds) 1997. The Political Economy of South-East Asia. Melbourne: Oxford University Press.

Rose, Mary B. 1993. 'Beyond Buddenbrooks: The Family Firm and the Management of Succession in Nineteenth-Century Britain'. In Entrepreneurship, Networks and Modern Business, edited by Jonathan Brown and Mary B. Rose, pp. 127-142. Manchester: Manchester University Press.

Searle, Peter 1999. The Riddle of Malaysian Capitalism: Rent-seekers or Real Capitalists? Honolulu: University of Hawai'i Press.

Sharma, Pramodita 2004. 'An Overview of the Field of Family Business Studies: Current Status and Directions for the Future'. Family Business Review 17: 1-36

Sharma, Pramodita, James J. Chrisman and Jess H. Chua 1997. 'Strategic Management of the Family Business: Past Research and Future Challenges'. Family Business Review 10 (1): 1-35.

Sharp, Ilsa 2009. Path of the Righteous Crane: The Life and Legacy of Eu Tong Sen. Singapore: Landmark Book Pte Ltd.

Tàpies, Josep, and John L. Ward (eds.) 2008. Family Values and Value Creation: The Fostering of Enduring Values Within Family-owned Businesses. Basingstoke: PalgraveMacmillan.

Toyad, Jacqueline, and Anandhi Gopinath 2010. 'First Family of Pewter'. The Edge 8 March: Op10-12.

Wade, Robert 1990. Governing the Market: Economic Theory and the Role of Government in 
Edmund Terence Gomez and Wong Yee Tuan

East Asian Industrialization. Princeton: Princeton University Press.

Whitley, Richard 1992. Business Systems in East Asia: Firms, Markets and Societies. London: Sage Publications.

Wong Sui Loon 1985. 'The Chinese Family Firm: A Model'. The British Journal of Sociology 36 (1): 58-72.

Wong Yee Tuan 2010. 'More Than a Tea Planter: John Archibald Russell and his Businesses in Malaya, 1899-1933'. The Journal of Malaysian Branch of the Royal Asiatic Society (JMBRAS) 83 (1): 29-51.

Yeung, Henry Wai-chung 2006. Chinese Capitalism in a Global Era: Towards a Hybrid Capitalism. London: Routledge. 